\title{
Reviewing the Pathophysiology Behind the Advances in the Management of Giant Cell Arteritis
}

Alia Z. Al-Mousawi · Sam P. Gurney • Alice R. Lorenzi •

Ute Pohl · Margaret Dayan · Susan P. Mollan

Received: January 3, 2019 / Published online: March 1, 2019

(C) The Author(s) 2019 first ever licensed treatment for GCA. Further potential therapies are emerging owing to our enhanced understanding of the pathophysiology of the disease. Other improvements in the care of our patients are rapid access pathways and imaging techniques, such as ultrasound, which are becoming part of modern rheumatology practice in the UK, Europe and beyond. These have been highlighted in the literature to reduce delay in diagnosis and improve longterm outcomes for those investigated for GCA.

Keywords: Anterior ischaemic optic neuropathy; Giant cell arteritis; Glucocorticoid toxicity; Interleukin-6; Large vessel vasculitis; Side-effects; Temporal arteritis; Tocilizumab; Vision

\section{INTRODUCTION}

Giant cell arteritis (GCA) is an idiopathic granulomatous vasculitis primarily involving medium- and large-calibre branches of the aorta [1]. It is the most common vasculitis in those of Caucasian ancestry aged above 50 years and exhibits a female preponderance [2-4]. This often-elusive condition if left untreated can lead to sight-threatening complications [5]. The mainstay of therapy in GCA has long been glucocorticoids (GC), which in themselves confer significant morbidity [6]. It is 
increasingly recognised that although GCA is traditionally seen as a GC-responsive disease, therapy typically lasts between 18 and 24 months with all requiring high dose therapy initially and some requiring long-term therapy, and when studied in the context of clinical trials only $15-20 \%$ of patients achieve long-term remission [7], highlighting the need for alternative therapies [8]. This review article is based on previously conducted studies and will present the recent advances in the diagnostic and therapeutic armamentarium in GCA. This article is based on previously conducted studies and does not contain any studies with human participants or animals performed by any of the authors.

\section{EPIDEMIOLOGY AND RISK FACTORS}

The lifetime risk of developing GCA is $1 \%$ for women and $0.5 \%$ for men [9] with a reported worldwide incidence ranging between 1 in 100,000 and 30 in 100,000 [10]. This appears to be related to a number of factors, including age, latitude, genetic susceptibility and ethnic background [9-22]. Amongst these well-established risk factors, age is widely regarded as the most significant. In a cross-sectional study conducted in northern Spain, a near 20-fold increase in the incidence of GCA was reported between those in their 6th decade of life as compared to those in their 9th decade. Similar trends have also been reported by studies conducted in the UK [12], Scandinavia [13, 14], Italy $[15,16]$ and the USA [17-20].

GCA most commonly affects those of northern European and Scandinavian descent [21]. This in part seems to be attributable to genetic factors; of particular interest have been the major histocompatibility complex (MHC) genes [22-26]. Most recently, a large genomewide association study in GCA was conducted on 1651 cases and 15,306 controls from six countries of European ancestry [24]. This revealed the human leucocyte antigen (HLA) class II gene loci as those with the strongest association to GCA susceptibility and specifically highlighted $D R B 1{ }^{*} 04, D Q A 1{ }^{*} 03$ and
$D Q B 1{ }^{*} 03$ alleles as those contributing most significantly to this signal. This data builds on the previous body of evidence describing a strong association between $H L A-D R B 1{ }^{*} 04$ carrier status and an increased risk of GCA [25]. Interestingly, a higher population frequency of the $H L A-D R B 1{ }^{*} 04$ allele has been reported in more northerly latitudes [26], providing insight into the potential determinants of the geographic variability of GCA incidence.

MHC class I genes have also been implicated as risk factors in GCA, with a strong association being described between the propensity for GCA and the HLA-B gene locus [24, 26, 27]. Further, genotype interrogation of the MHC class I chain-related gene A (MICA), which encodes putative stress-inducible heat shock elements [26], has been shown to confer susceptibility to GCA in a northern Spanish cohort [27]. This appeared to be independent of linkage disequilibrium with HLA-B and exhibited a cumulative risk effect when concurrent with the HLA-B15 haplotype or the HLA-DRB ${ }^{*} 04$ allele [27].

Of the non-MHC genes found to predispose to GCA, the strongest evidence is in support of the interleukin-12 $\beta$ (IL-12 $\beta$ ) gene [22]. Genotyping by immunochip array performed on a cohort compromising of 997 Spanish and Italian cases and 2775 controls reported the largest signal outside the MHC region to be the single nucleotide polymorphism (SNP) rs755374 in the IL-12 $\beta$ gene locus [23]. This relationship was confirmed in a further four cohorts of European ancestry. Remarkably, this gene is traditionally associated with an increased risk of Takayasu's arteritis [23]. Other non-MHC genes, such as TNF- $\alpha$ microsatellite [28] and interleukin-6 (IL6) [29], appear to be of emerging significance. However, better powered studies of more diverse populations are needed to validate their importance as risk genes.

\section{IMMUNOPATHOBIOLOGY}

GCA is a T cell driven disease characterised by the formation of vessel wall granulomas, intimal hyperplasia and end-organ ischaemia $[21,30]$. It is a disease of immune dysregulation 
and, as such, emerging data not only sheds light on the importance of Th1 and Th17 pathways but also on the role of innate immunity in propagating and sustaining the inflammatory milieu (Fig. 1) [30-35].

\section{Vascular Dendritic Cells}

In health, immature vascular dendritic cells (DCs) positioned at the adventitial-medial interface migrate to lymphoid organs if activated, thus preserving the immune-privileged status of the vessel wall [36]. In GCA however, DCs undergo activation and maturation within the arterial vessel wall and remain in situ $[37,38]$. They express surface molecules and chemokines which recruit and activate local innate immune cells, such as monocytes and fibroblasts, whilst also crucially gaining the ability to activate naïve CD4+ T cells [38-40]. It is as yet unclear what triggers this breach in tolerance and though some have postulated a role for infectious agents [41-43], the literature remains contradictory $[44,45]$.

\section{Macrophages}

Macrophages are known to secrete matrix metalloproteinases, which degrade the internal elastic lamina and smooth muscle cells within the media, promoting the migration and proliferation of myofibroblasts into and within the intima $[10,46]$. This produces a classically hyperplastic intima leading to luminal compromise. Importantly, macrophages release IL- 6 and IL-1 $\beta$, potent cytokines required for the differentiation of Th17 effector cells [36, 37, 46, 47]. Interestingly, the circulating levels of IL-6 have

Proceeding from an unknown trigger, there is an abnormal maturation of vascular dendritic cells (DC) in the adventitia of the large vessel walls. These activated DC recruit and activate cluster differentiation (CD) 4+ naïve T cells.

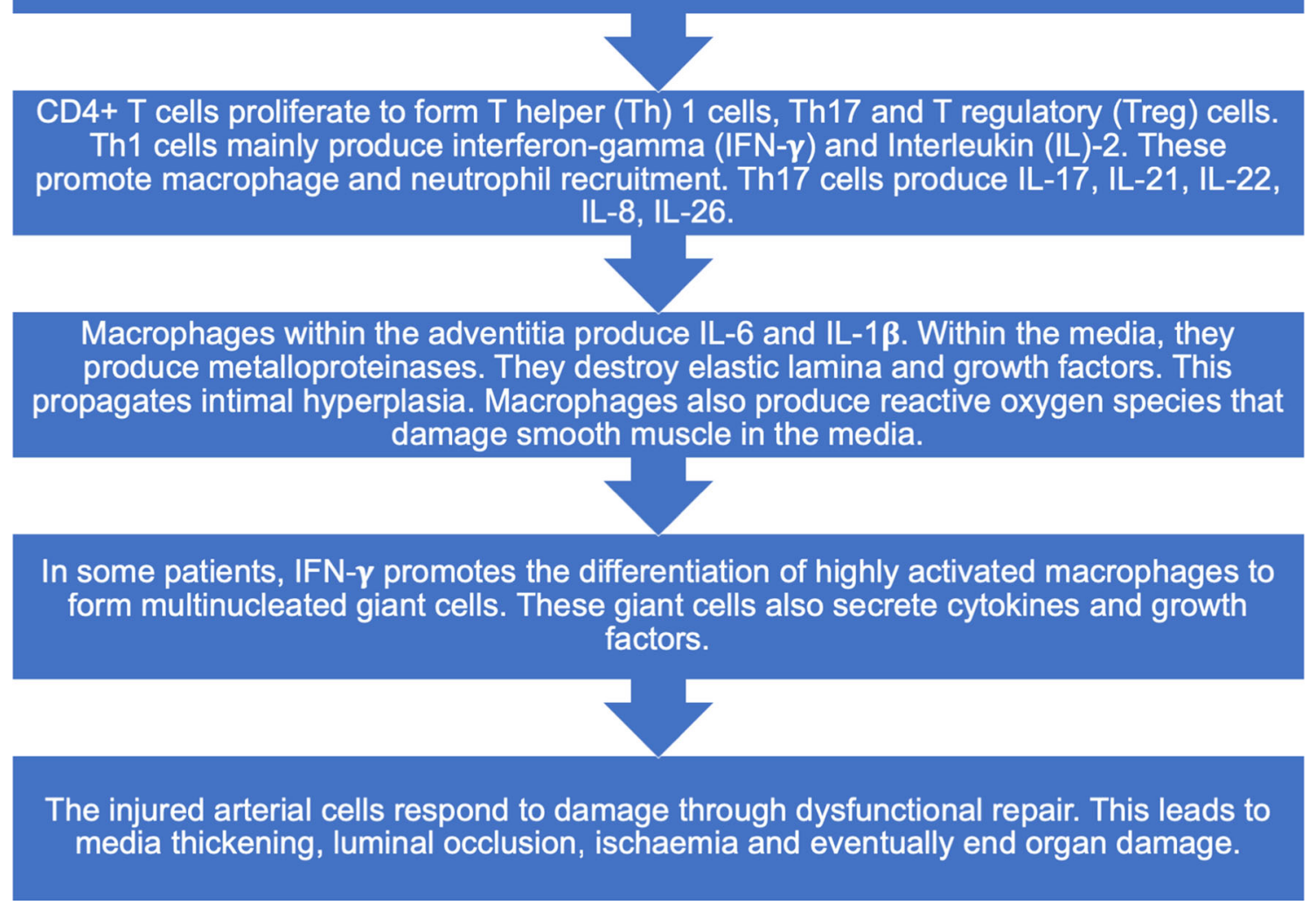

Fig. 1 Flow diagram on the key immunopathophysiology of GCA 
been found to correlate with the severity of the acute inflammatory response in GCA and fluctuate in line with disease activity [32]. However, higher levels of IL- 6 also appear to confer a lower risk of ischaemic complications, a puzzling conundrum thought to be related to the pro-angiogenic effects of IL-6 [33, 48, 49].

\section{Th1 and Th17}

Two main lineages of CD4+ T cells are involved in the pathogenic inflammatory response which drives GCA. Th1 cells differentiate in the presence of IL-12, thought to be produced by activated vasDCs [32]. These effector T cells are responsible for the secretion of interferon- $\gamma$ (IFN- $\gamma$ ), a potent activator of macrophages and heavily implicated in promoting mural infiltration, as well as giant cell and granuloma formation $[35,50,51]$. Th17 cells on the other hand are reliant on IL- 6 and IL- $1 \beta$ from macrophages to differentiate. They are characterised by the production of IL-17 but also secrete IL23, GM-CSF and IL-22 among others [35, 52]. These cytokines are implicated in recruiting innate immune cells, propagating local mesenchymal cell proliferation and activation of hepatocytes to secrete acute phase proteins [32].

In contrast to IL- 6 and IL-17, which appear to wax and wane with disease activity and are highly responsive to GC, elevated levels of IL-12 and IFN- $\gamma$ persist within the serum of patients and within temporal artery samples despite months of GC treatment [33]. Moreover, higher levels of IL-12 and IFN- $\gamma$ correlate with a greater burden of ischaemic complications [33, 52]. These findings lend credence to the idea of a phasic inflammatory process, where the Th17 (IL-6/IL-17)-mediated pathway, which is GC responsive, drives inflammation in early GCA, while Th1 (IL-12/IFN- $\gamma$ )-mediated mechanisms promote chronicity and are poorly GC responsive [30-33]. This further explains the histological findings of a sustained vasculitis and the development of aortic aneurysms long after the commencement of GC therapy [33] and, most importantly of all, the suboptimal numbers of patients that actually achieve long-term remission despite GC therapy [7].

\section{CLINICAL PRESENTATION}

Giant cell arteritis is renowned for its insidious onset, heterogenous presenting features and constitutional symptoms, which often contribute to diagnostic uncertainty and delay in treatment [34]. Up to $40 \%$ of patients present atypically [53] and the pattern of disease involvement ranges from cranial involvement such as anterior ischaemic optic neuropathy (Fig. 2), retinal arterial occlusions (Fig. 2) and choroidal infarction (Fig. 3) to extracranial such as symptoms of polymyalgia rheumatica or large vessel vasculitis (Table 1); they can be mutually exclusive or a combination of the spectrum. This condition can therefore present to many specialists which can further compound a diagnostic delay [34]. Many studies have examined the presenting features, and among those with the highest positive predictive value include scalp tenderness and/or jaw claudication (Fig. 4) [54, 55]. The natural history of the disease varies, and because of the advent of targeted treatment disease stratification is required, with clear definitions of disease states (Table 2) [8].

\section{SECURING A DIAGNOSIS OF GCA}

Securing a diagnosis of GCA can be challenging, and requires a prompt, thorough history, full clinical examination and a combination of investigations. Laboratory findings in GCA typically reflect a pro-inflammatory picture with a prolonged ESR, increased plasma viscosity, raised CRP, thrombocytosis, raised alkaline phosphatase and a normochromic normocytic anaemia [56]. CRP is the most sensitive individual serological marker [57] and should always be checked. An isolated raised ESR with normal CRP should prompt a search for alternative diagnoses (e.g. myeloma, connective tissue disease).

Given that the standard treatment confers significant risk of morbidity most agree that a confirmatory investigational test is required. Temporal artery biopsy (TAB) allows for a histological diagnosis, abrogates diagnostic doubt and provides justification for the use of 


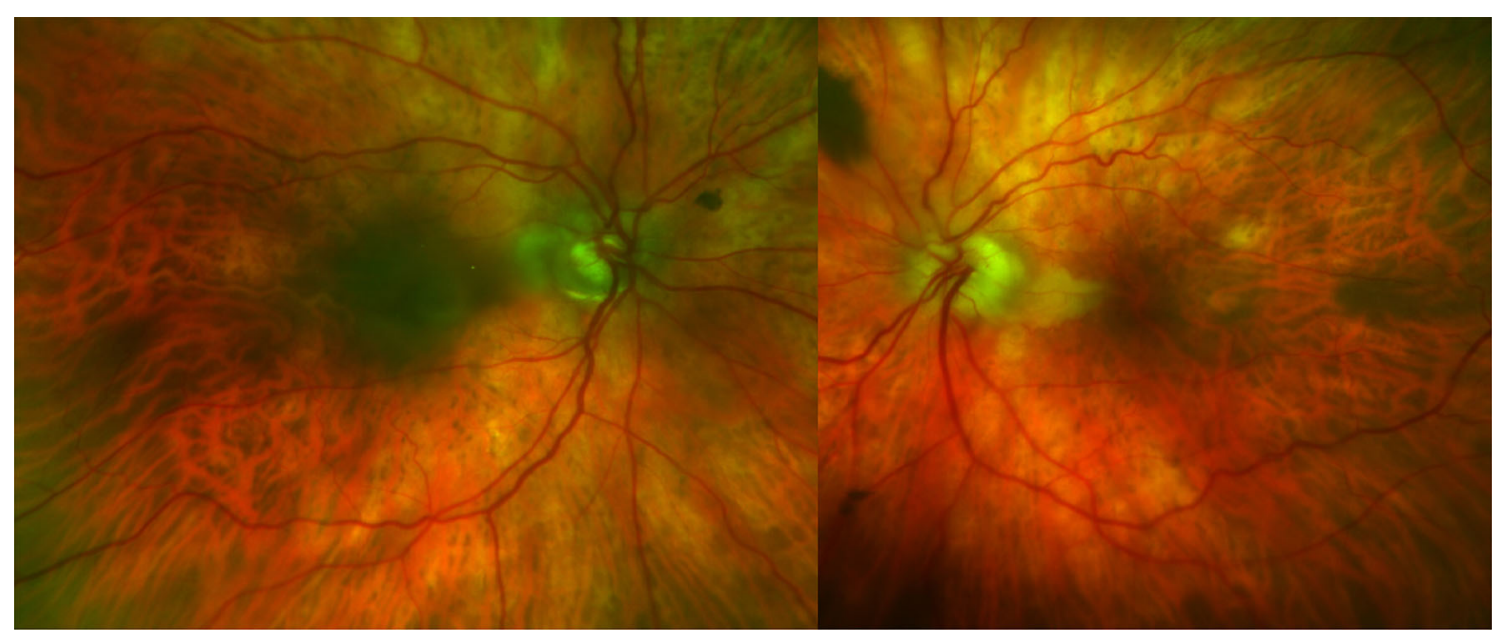

Fig. 2 An 85-year-old woman presented with bilateral visual loss. Right visual acuity 6/18, left perception of light. Erythrocyte sedimentation rate (ESR) $88 \mathrm{~mm} / \mathrm{h}$ and C-reactive protein (CRP) 66 (normal range less than 5).
Temporal artery ultrasound scan positive halos bilaterally. Colour images show bilateral cilioretinal artery occlusions and left arteritic anterior ischaemic optic neuropathy

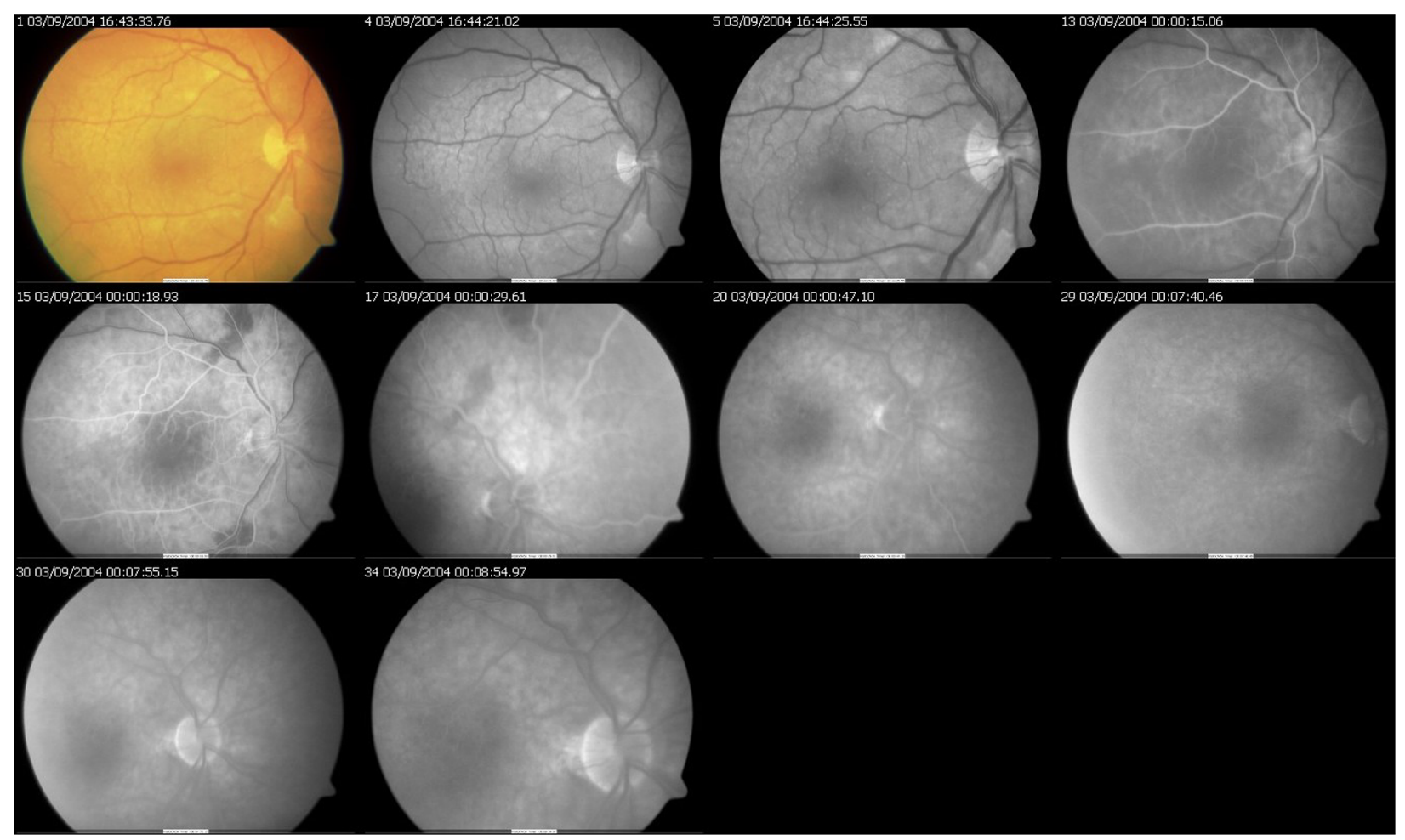

Fig. 3 An 82-year-old man with transient visual disturbance of the right eye, right temporal tenderness and jaw claudication. ESR $66 \mathrm{~mm} / \mathrm{h}$. Cotton wool spots along superotemporal and inferotemporal retinal vascular arcades. Fluorescein angiography sequence showed choroidal ischaemia in these areas. Temporal artery biopsy was positive 
Table 1 Typical signs and symptoms reported in GCA $[13,53-56]$

\begin{tabular}{|c|c|}
\hline \multirow[t]{5}{*}{ Systemic symptoms } & Fever \\
\hline & Night sweats \\
\hline & Loss of appetite \\
\hline & Unintentional weight loss \\
\hline & Mood change \\
\hline \multirow{7}{*}{$\begin{array}{l}\text { Cranial signs and } \\
\text { symptoms }\end{array}$} & Temporal cutaneous hyperalgesia \\
\hline & Jaw claudication \\
\hline & New onset headache \\
\hline & $\begin{array}{l}\text { Abnormalities of the temporal } \\
\text { artery on examination }\end{array}$ \\
\hline & Scalp necrosis \\
\hline & Tongue necrosis \\
\hline & Rarely stroke \\
\hline \multirow[t]{11}{*}{$\begin{array}{l}\text { Ophthalmic signs } \\
\text { and symptoms }\end{array}$} & $\begin{array}{l}\text { Transient monocular visual loss } \\
\text { (amaurosis fugax) }\end{array}$ \\
\hline & Permanent loss of vision \\
\hline & $\begin{array}{l}\text { Anterior ischaemic optic } \\
\text { neuropathy (Fig. 2) }\end{array}$ \\
\hline & $\begin{array}{l}\text { Central retinal artery occlusion } \\
\text { (Fig. 2) }\end{array}$ \\
\hline & Branch retinal artery occlusion \\
\hline & $\begin{array}{l}\text { Posterior ischaemic optic } \\
\text { neuropathy }\end{array}$ \\
\hline & Choroidal infarction (Fig. 3) \\
\hline & Transient diplopia \\
\hline & Persistent diplopia \\
\hline & $\begin{array}{l}\text { Isolated oculomotor cranial nerve } \\
\text { palsy }\end{array}$ \\
\hline & $\begin{array}{l}\text { Multiple oculomotor cranial } \\
\text { nerve palsies }\end{array}$ \\
\hline \multirow{4}{*}{$\begin{array}{l}\text { Large vessel } \\
\text { manifestations }\end{array}$} & Aoritis \\
\hline & Limb claudication \\
\hline & Thoracic aneurysms \\
\hline & Abdominal aneurysms \\
\hline
\end{tabular}

\section{Temporal cutaneous hyperalgesia}

Jaw claudication

Recent-onset headache

Fig. 4 Clinical factors predicting a positive temporal artery biopsy in order of magnitude. Adapted from González-López et al. [55]

Table 2 Definitions of disease activity in GCA. Adapted from Coath et al. [8]

\section{Terminology Definition}

Relapse $\quad$ Recurrence of signs or symptoms of GCA attributable to GCA as determined by the healthcare professional necessitating an increase in treatment in a GCA patient who has previously responded to treatment

Refractory People with GCA who never achieve remission, regardless of treatment with a course of glucocorticoids, which would be considered adequate in others to induce remission. Lower dose regimens may constitute optimal care if the maximum safe dose of glucocorticoid must be exceeded in order to control disease e.g. in glucocorticoid-induced psychiatric disturbance, pancreatitis, or uncontrolled diabetes or hypertension

Remission Absence of signs or symptoms of GCA.

prolonged courses of GC and the morbidity which accompanies their use. Histologically, the inflammatory infiltrate in GCA is 

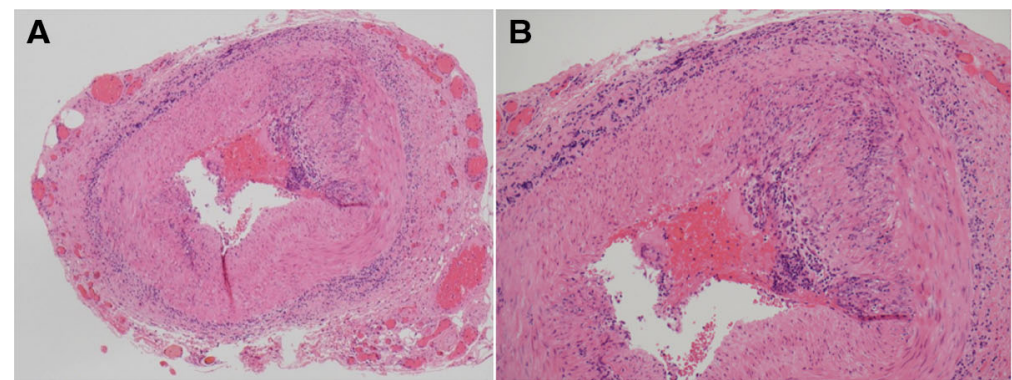

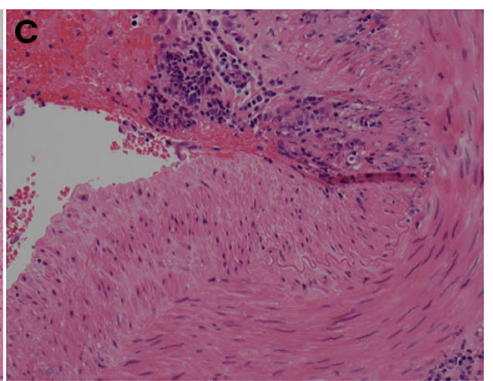

Fig. 5 Active GCA. a Transverse arterial profile demonstrating segmental chronic inflammation and thickening of intima and circumferential chronic inflammation of adventitia (patchy concentric bilayer pattern), $\mathrm{HE} \times 40$ magnification. b Close-up of a; partial transverse arterial profile revealing granulomatous lymphohistiocytic inflammation in intima and predominantly lymphocytic inflammation in adventitia, HE $\times 100$ magnification. C Close-up of $\mathbf{a} / \mathbf{b}$; partial transverse arterial profile showing granulomatous lymphohistiocytic inflammation in intima and discontinuous elastic lamina, $\mathrm{HE} \times 200$ magnification

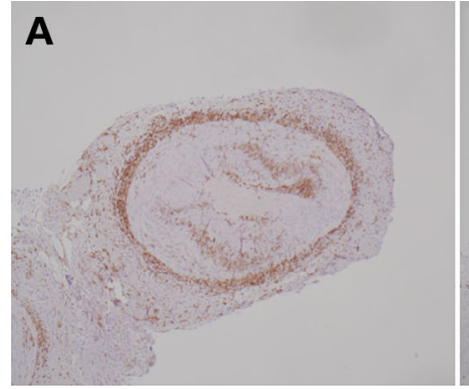

B

Fig. 6 The case illustrated matches most closely the concentric bilayer pattern, although the media is also focally inflamed, overlapping with the panarteritic pattern. The cellular composition is dominated by histiocytes/macrophages in the intima and $\mathrm{T}$ lymphocytes in the adventitia, with $\mathrm{CD} 4+$ lymphocytes being the commonest subtype (a), lesser numbers of CD8+ lymphocytes

predominantly composed of histiocytes/macrophages and CD4-positive lymphocytes, with variable involvement of the three arterial layers (Fig. 5), often showing only segmental/sectorial inflammation in parts of the arterial wall. The lymphocyte population usually includes lesser numbers of CD8+ cytotoxic lymphocytes and even small clusters of CD20+ B lymphocytes (Fig. 6). Focal fusion of histiocytes and formation of multinucleate giant cells are seen (Fig. 7), but these are not required for the diagnosis. Morphologically, four different inflammatory patterns can be differentiated with the panarteritic pattern being the most (b) and a few CD20+ lymphocytes (c). Large multinucleate giant cells are not seen; however, occasional binucleate macrophages are noted. The elastic lamina displays breaks and patchy discontinuation, as well as focal reduplication

common (69\%), followed by the concentric bilayer pattern (18\%) (Fig. 6) with involvement of intima and adventitia, and least common, two adventitial patterns, with and without local invasion of the media ( $7 \%$ and $6 \%$, respectively) [58]. The inflammation typically results in breaks, segmental loss and reduplication of the elastic lamina. This is best seen on elastin stain that highlights disruption, segmental discontinuation and focal reduplication of elastica (Fig. 8). This may cause critical luminal narrowing and aneurysm formation. When the active phase of the disease has vanished, inflammatory cell infiltrates may be absent but 

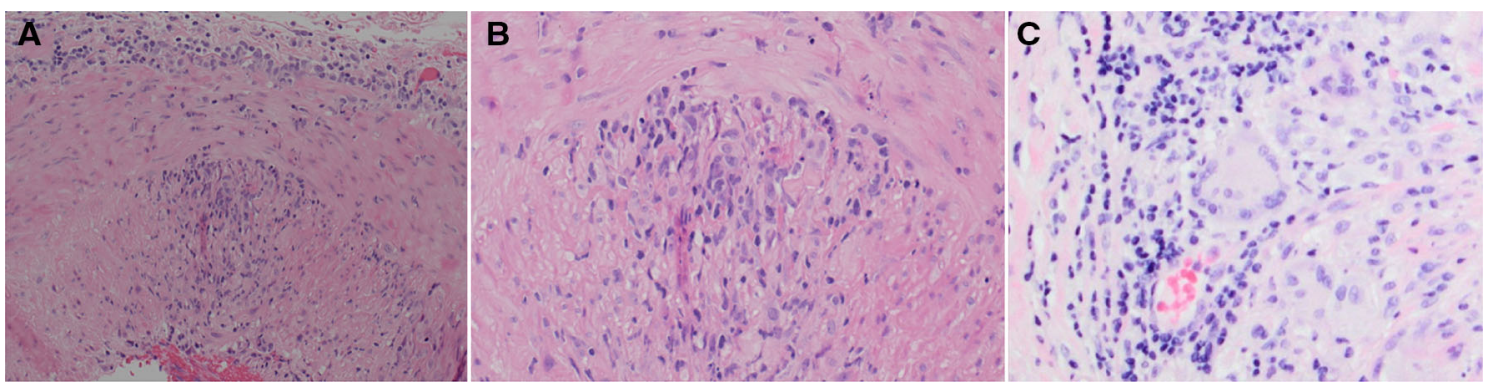

Fig. 7 a Partial transverse arterial profile displaying granulomatous lymphohistiocytic inflammation in intima and adventitia, with minor inflammatory changes in media, $\mathrm{HE}$ $\times 200$ magnification. b Close-up of a; Intima with

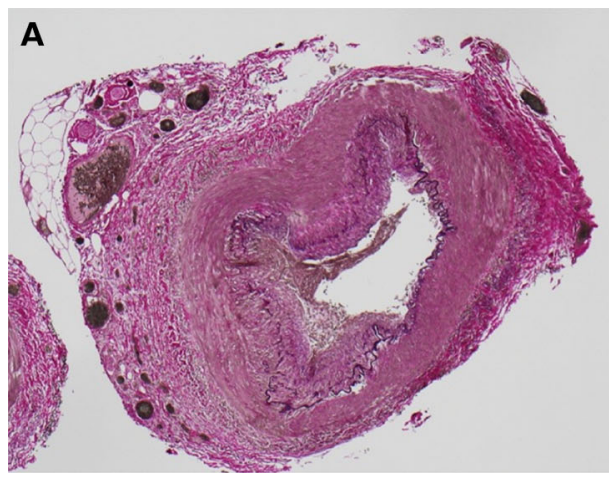

Fig. 8 a Elastin stain highlights disruption, segmental discontinuation and focal reduplication of elastica (black lines), EvG $\times 40$ magnification. $\mathbf{b}$ Close-up of a;

intimal-medial scarring and injury to the elastic lamina often remains, allowing a diagnosis of 'healed arteritis'. A recent report links the CD68+ (cluster of differentiation 68+) macrophage marker in TABs with those who are refractory to initial GC tapers, and those eventually placed on immunomodulatory therapy [59].

The sensitivity of TAB can vary between $39 \%$ and $91 \%$ because of skip lesions, inadequate sample length and the initiation of GC prior to biopsy $[60,61]$. The resultant high false negative rate could potentially lead to patients being continued on GC as a precautionary measure. The true false negative rate of TAB cannot be estimated with certainty as the clinical diagnosis of TAB-negative, TAUS-negative GCA cannot be confirmed diagnostically. Consequently, the European League Against Rheumatism (EULAR) granulomatous inflammation, showing focal fusion of histiocytes, forming multinucleate giant cells, HE $\times 400$ magnification. c Large multinucleate giant cell in intima, HE $\times 400$ magnification

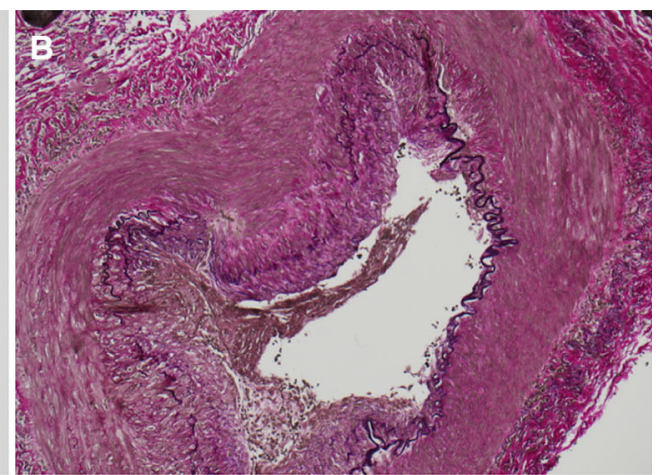

disruption, segmental discontinuation and focal reduplication of elastica (black lines), EvG $\times 100$ magnification

recommendations on the diagnosis of large vessel vasculitis have been updated to include the use of non-invasive imaging techniques to assist or even supersede TAB in certain circumstances [62]. The first study examining the diagnostic application of ultrasound (USS) in GCA was conducted in 1997 by Schmidt et al. [63]. They assessed 30 patients for the presence of:

1. Halo sign - analogous to oedema of the temporal artery wall (Fig. 9)

2. Stenosis and

3. Occlusion of the temporal artery

They found the halo sign to have a sensitivity of $73 \%$ and specificity of $100 \%$ when compared with the final diagnosis. Three meta-analyses have provided an evidence base for the role of USS in the diagnosis of GCA [64-66]. Typically reported sensitivities range between $68 \%$ and 

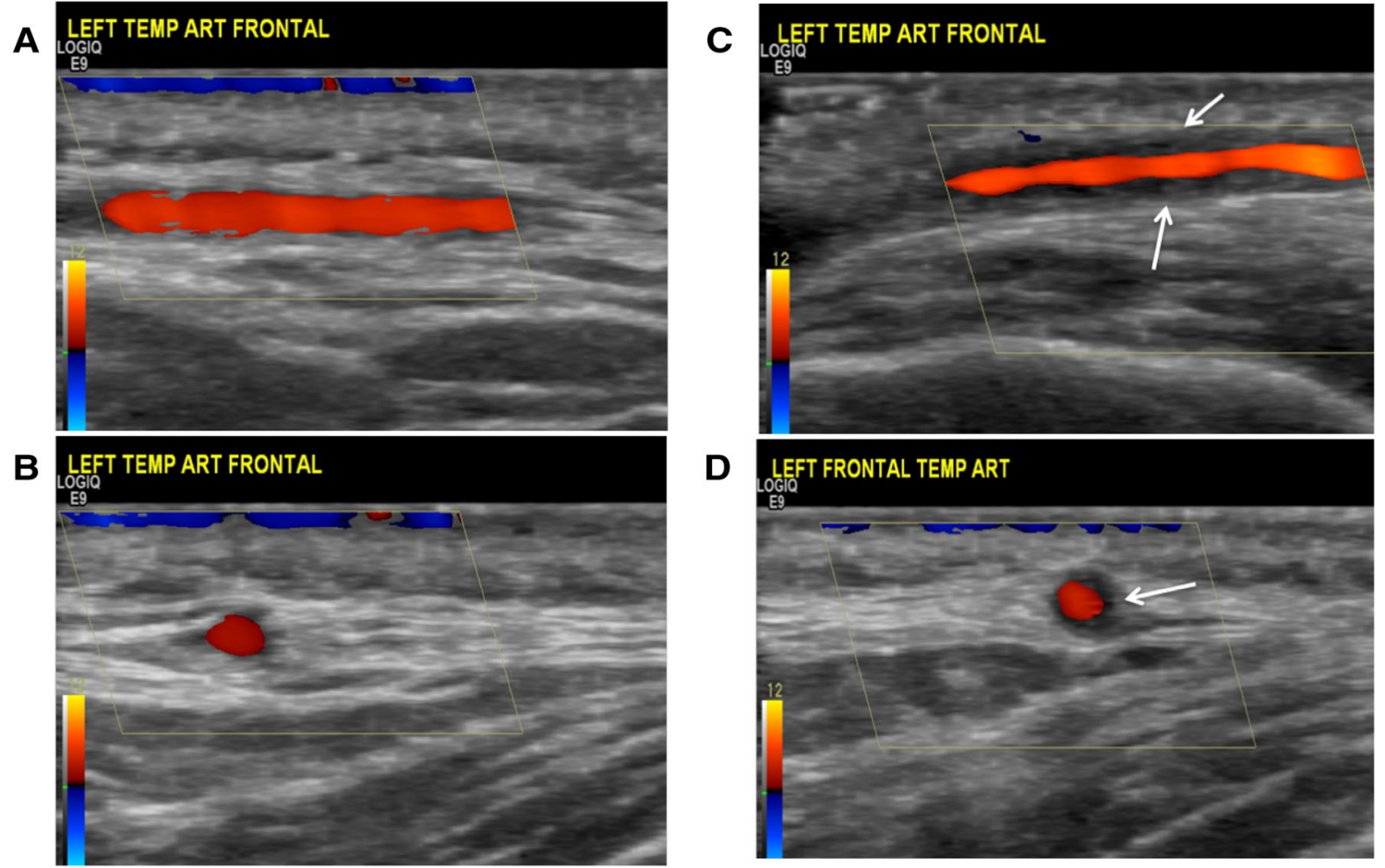

Fig. 9 Temporal artery ultrasound images showing a longitudinal and $\mathbf{b}$ cross-sectional images of a normal artery; $\mathbf{c}$ longitudinal and $\mathbf{d}$ cross-sectional image of the non-compressible, hypoechoic halo sign

$75 \%$ and specificities between $83 \%$ and $92 \%$, when either final histological or clinical diagnosis is used as the comparator gold standard. It should be noted that the ability to detect a halo sign declines rapidly after the initiation of glucocorticosteroid (GC) with sensitivity falling to below $50 \%$ at 4 days $[64,65,66]$. The specificity of the halo sign is increased with the use of the 'compression test': a true halo will not disappear if the probe is used to compress the temporal artery [67].

The EULAR taskforce for imaging in large vessel vasculitis guideline recommended USS as the first-line imaging modality for predominantly cranial GCA in centres where experience is at hand, as the test is less invasive and thus well tolerated by elderly and often frail individuals, the result is not delayed and it is costeffective [62]. Experience of USS for GCA has led to the reduction in numbers of TABs being performed at some centres [68, 69]. Additionally, USS of both the temporal artery and the axillary artery increases the yield of the diagnosis [68].
For large vessel GCA, other imaging techniques are emerging as clinically useful. ${ }^{18} \mathrm{~F}-f l u-$ orodeoxyglucose positron emission tomography $\left({ }^{18} \mathrm{~F}-\mathrm{FDG}\right.$-PET) is usually combined with lowdose computed tomography (CT) assessing disease activity and extent of involvement [70]. Although large vessel imaging is sensitive to GC therapy, uptake can persist despite treatment and absence of clinical symptoms in some. Research areas in GCA imaging include super high-resolution magnetic resonance imaging (MRI) of the superficial and extracranial arteries demonstrating arterial wall thickening with peri-adventitial and mural contrast enhancement [71] and transdermal optical coherence tomography (OCT) of the superficial temporal artery [72].

\section{MANAGEMENT}

Suspected GCA remains a medical emergency, and the number of cases investigated for GCA is rising [73]. Rapid access clinics, often with access to TA USS and combined 
ophthalmology/rheumatology clinical expertise, have been reported to improve patient outcomes $[62,68]$. It should be noted that excluding GCA as a diagnosis is also important to prevent patients without disease being exposed to prolonged GC exposure unnecessarily.

Glucocorticosteroids remain the gold-standard treatment in GCA; it is a consensus-based approach rather than one supported by wellpowered prospective studies [56]. Short-term side effects such as GC-induced psychosis can be challenging to treat and long-term GC use is associated with a multitude of adverse effects including an increased susceptibility to infections, osteoporotic fractures, diabetes, hypertension, glaucoma, gastric ulcer disease and mood disorders, amongst others [74]. A recent study by Proven et al. reported that $86 \%$ of patients developed at least one GC-related complication over a 10-year period [75]. These worrying findings in the context of an aged population with a high baseline burden of comorbidities have prompted research into GCsparing agents in the form of traditional diseasemodifying antirheumatic drugs (DMARDs) and, more recently, targeted biologic agents.

\section{DMARDS}

To date, only three randomised, placebo-controlled trials have examined the efficacy of methotrexate (MTX) as an adjunctive GC-sparing agent and these have reported conflicting results [76-78]. A meta-analysis of these studies revealed that patients treated with MTX had a significant, though modestly reduced risk of relapse compared with placebo, and this on lower cumulative GC doses [79]. Notably, however, and despite the apparent GC-sparing effect of MTX, there was no significant difference in the rate of drug-related adverse events between the intervention and placebo-controlled groups [79]. These studies were conducted with low-dose MTX and in patients in whom GC titration from low doses had failed on several occasions, which may explain why the results were marginal.

Leflunomide has been shown to be effective in Takayasu's arteritis and other T cell driven diseases such as rheumatoid arthritis. In the few retrospective case-series reported in the literature, statistically significant GC-sparing effects have been witnessed though these equate to minimal absolute reductions in cumulative GC doses [80, 81]. A paucity of well-powered prospective studies assessing leflunomide efficacy in GCA means it does not yet appear to have a role in GCA. However, a recent openlabel prospective study conducted by Hočevar et al. [82] has shown some promise, supporting the need for well-powered randomised controlled trials (RCTs) to further interrogate the role of this drug.

Other conventional DMARDs such as azathioprine [83], cyclophosphamide [84] and mycophenolate [85] have not been shown to be superior to GC alone, whilst ciclosporin has been deemed ineffective [86]. Other adjunctive therapy, such as aspirin, has previously been supported in GCA, but clinical evidence is lacking [87].

\section{BIOLOGICS}

\section{IL-6 Blockade}

With the emergence of an apparently central role for IL-6 in the pathogenesis of GCA, it is no surprise that biologic agents that modulate this cytokine and subsidiary molecules and receptors have been of increasing interest in the search for novel therapeutic agents. Tocilizumab (TCZ), a humanised monoclonal antibody to the IL-6 receptor, has shown exciting results in phase II [88] and phase III trials [89]. Villiger et al. [88] conducted the first RCT of TCZ in GCA, where 30 patients with new-onset or relapsing disease were randomised to receive either weekly TCZ infusions or placebo, both with a tapering GC regimen. At week $12,85 \%$ of the TCZ group had achieved clinical and biochemical remission as compared with only $40 \%$ of those in the placebo group $(p=0.03)$. Similarly, at 1 year, $85 \%$ of the TCZ group had remained relapse-free versus a mere $20 \%$ of the placebo group $(p=0.001)$, all whilst conferring a significant GC-sparing effect (in favour of TCZ). 
Subsequently, the Giant Cell Arteritis Actemra (GiACTA) trial was conducted by Stone et al. [89]. This large phase III, multicentre, double-blind, placebo-controlled study examined the efficacy of TCZ to induce and sustain remission to 1 year [89]. A total of 119 patients with newly diagnosed GCA and 132 patients with refractory disease were enrolled and randomised to one of four arms: weekly or fortnightly dosing of TCZ with a 26-week prednisolone taper or placebo plus a 26-week or 52 -week prednisolone taper. At 1 year, patients in the TCZ groups were significantly more likely to have achieved sustained remission as compared with both the 26-week and 52-week GC taper groups, and at just over half the cumulative GC dose. However, despite the impressive GC dose reduction over the course of the study, there was no significant difference in the rate of adverse events between the TCZ and placebocontrolled groups. Villiger et al. [88] reported an increased infection rate in the treated group and this was not found in GiACTA [89]. Extrapolating safety data from rheumatoid arthritis must be met with caution because of the significant age difference between the two distinct disease groups [90]. Of particular concern in the GCA population are diverticular disease, transient neutropenias, and elevations of triglycerides and deranged liver function tests.

It should be noted that in GiACTA both placebo arms had a significantly faster GC taper than used in routine clinical practice and thus the real-life GC-sparing effect may prove to be less marked. Also $1 / 3$ patients had diagnosis based on large vessel imaging, which is currently not routine clinical practice. The 2-year open-label outcomes for this trial are currently anticipated. These results will shed light on the long-term safety profile and efficacy of TCZ at maintaining disease-free remission, and will help elucidate the extent of its GC-sparing effects including the potential for GC-free remission.

Nonetheless, these trials have provided the evidence-base for a paradigm shift with tocilizumab being the first ever drug licensed by the Food and Drug Agency (FDA) and the European Medicines Agency (EMA) for GCA [91].

\section{TNF- $\alpha$ Blockade}

Amongst its many pro-inflammatory functions, TNF- $\alpha$ is a potent chemotactin and is known to activate macrophages, T cells and local mesenchymal cells, thereby fuelling the inflammatory milieu [35]. However, whilst monoclonal antibodies antagonising the function of TNF- $\alpha$ have become a fixture in the treatment of autoimmune inflammatory conditions, the results from phase II RCTs conducted in GCA have been disappointing [92-94]. These findings suggest that although TNF- $\alpha$ plays an important role in the inflammatory response in GCA there may be other circumventing pro-inflammatory pathways, which despite TNF- $\alpha$ blockade, remain active.

\section{IL-12/IL-23 Blockade}

We have discussed the role of Th1 and Th17 pathways in the immunopathobiology of GCA, Th17 being implicated in the early, GC-responsive inflammatory phase and Th1 in the chronic, poorly GC-responsive phase of the disease. IL-12 and IL-23 are key cytokines which regulate $\mathrm{T}$ cell differentiation into Th1 and Th17 effector cells, respectively [30-34]. Enter ustekinumab, a monoclonal antibody to the p40 subunit, common to both IL-12 and IL-23. An open-label prospective study of ustekinumab in refractory GCA was performed by Conway et al. [95]. Twenty-five patients with refractory GCA were commenced on a weaning course of prednisolone and subcutaneous ustekinumab injections every 12 weeks. At 1 year, none of the participants had experienced a relapse and $24 \%$ had achieved GC-free remission. Reductions in CRP levels and daily GC doses were found to be significant. Though the results of this study are not overwhelming, they do provide insight into the potential therapeutic capacity of ustekinumab in GCA. A similar open-label study is currently recruiting, results of which are expected in 2020 [96]. 


\section{T Cell Activation}

Abatacept (CTLA4-Ig) is a recombinant fusion protein which interferes with the CD28-mediated co-stimulation required for $\mathrm{T}$ cell activation. Langford et al. [97] examined the efficacy of abatacept in maintaining disease-free remission in patients with newly diagnosed or relapsing GCA in a multicentre, double-blind RCT. Forty-nine patients from 11 centres were commenced on the trial receiving high-dose prednisolone and four abatacept infusions over the course of 8 weeks. By week 12, 41 patients had achieved disease-free remission and were randomised to either continue on monthly abatacept or switch to placebo, both while continuing on a weaning GC regime. The study reported a minimally significant $(p=0.049)$ increase in relapse-free survival in the abatacept group at 1 year as well as a significant $(p=0.023)$ increase in the duration of remission in this group.

The authors comment that though the result of this study showed low-level significance, they felt this represented a clinically significant outcome [97]. A notable and possible confounding factor in the study design was that all participants received abatacept prior to randomisation as a means to induce remission in conjunction with high-dose GC. Though of course this design may help to detect safety issues early on in the trial, it may have inadvertently diluted the effect size through a carry-over effect in those subsequently randomised to the placebo group. As ever, better powered RCTs are required to further evaluate the efficacy of abatacept in GCA.

\section{IL-1ß Receptor Blockade}

IL-1 $\beta$ is a prerequisite cytokine for the differentiation of Th17 cells, which appear to play a central role in GCA [35]. Anakinra, a monoclonal antibody to the IL- $1 \beta$ receptor, is thus thought to be of potential therapeutic benefit. A small case series has been reported [98] and a phase III trial is now planned to compare the efficacy of anakinra as an adjunctive GC-sparing drug in GCA [99]. Gevokizumab, a recombinant monoclonal antibody to IL- $1 \beta$, is currently under investigation in a multicentre, doubleblind RCT [100].

\section{Other Avenues}

It as yet unclear what role, if any, humoral immunity plays in the pathogenesis of GCA. It has been postulated that given the integral role of B cells in the T cell life cycle, B cell depletion in the form of rituximab could be a potential therapeutic avenue [46]. Case reports have shown some benefit in select patient groups but further study is required [101]. An intriguing novel oral drug currently recruiting to phase II trials is baricitinib, a synthetic DMARD which targets the intracellular pro-inflammatory Janus kinase (JAK) family of enzymes [102]. Results from the GCA cohort are awaited.

\section{CONCLUSIONS}

Understanding of the immunopathophysiology of GCA has now translated into the first licensed targeted treatment for GCA, with an IL6 inhibitor, tocilizumab. This is the beginning of addressing the unmet need in GCA of GC toxicity and morbidity. The development and routine availability of non-invasive imaging in conjunction with clinical expertise is becoming the gold standard for practice in GCA.

\section{ACKNOWLEDGEMENTS}

Funding. No funding or sponsorship was received for this study or publication of this article.

Authorship. All named authors meet the International Committee of Medical Journal Editors (ICMJE) criteria for authorship for this article, take responsibility for the integrity of the work as a whole, and have given their approval for this version to be published.

Disclosures. Susan P. Mollan has undertaken consultancy work (speaker and advisory 
board fees) from Roche. Alice R. Lorenzi has received advisory board fees from Roche. Margaret Dayan, Alia Z. Al-Mousawi, Sam P. Gurney and Ute Pohl have nothing to disclose.

Compliance with Ethics Guidelines. This article is based on previously conducted studies and does not contain any studies with human participants or animals performed by any of the authors.

Data Availability. All data generated or analyzed during this study are included in this published article/as supplementary information files.

Open Access. This article is distributed under the terms of the Creative Commons Attribution-NonCommercial 4.0 International License (http://creativecommons.org/licenses/ by-nc/4.0/), which permits any noncommercial use, distribution, and reproduction in any medium, provided you give appropriate credit to the original author(s) and the source, provide a link to the Creative Commons license, and indicate if changes were made.

\section{REFERENCES}

1. Jennette JC, Falk RJ, Bacon PA, et al. 2012 revised international Chapel Hill consensus conference nomenclature of vasculitides. Arthritis Rheum. 2013;65(1):1-11.

2. Weyand CM, Goronzy JJ. Giant-cell arteritis and polymyalgia rheumatica. Ann Intern Med. 2003;139:505-15.

3. Salvarani C, Cantini F, Boiardi L, Hunder GG. Polymyalgia rheumatica and giant-cell arteritis. N Engl J Med. 2002;347:261-71.

4. González-Gay MA, Garcia-Porrua C. Epidemiology of vasculitides. Rheum Dis Clin North Am. 2001;27(4):729-49.

5. Kawasaki A, Purvin V. Giant cell arteritis: an updated review. Acta Ophthalmol. 2009;87:13-32.

6. Broder MS, Sarsour K, Chang E, et al. Corticosteroidrelated adverse events in patients with giant cell arteritis: a claims-based analysis. Semin Arthritis Rheum. 2016;46(2):246-52.
7. Dejaco C, Brouwer E, Mason JC, Buttgereit F, Matteson EL, Dasgupta B. Giant cell arteritis and polymyalgia: current challenges and opportunities. Nat Rev Rheumatol. 2017;13(10):578-92.

8. Coath F, Gillbert K, Griffiths B et al. Giant cell arteritis: new concepts, treatments and the unmet need that remains. Rheumatology (Oxford). 2018 Nov 12. https://doi.org/10.1093/rheumatology/ key326.

9. Crowson CS, Matteson EL, Myasoedova E, et al. The lifetime risk of adult-onset rheumatoid arthritis and other inflammatory autoimmune rheumatic diseases. Arthritis Rheum. 2011;63:633-9.

10. Borchers AT, Gershwin ME. Giant cell arteritis: a review of classification, pathophysiology, geoepidemiology and treatment. Autoimmun Rev. 2012;11(6-7):A544-54.

11. Gonzalez-Gay MA, Miranda-Filloy JA, Lopez-Diaz MJ, et al. Giant cell arteritis in northwestern Spain: a 25-year epidemiologic study. Medicine (Baltimore). 2007;86:61-8.

12. Smeeth L, Cook C, Hall AJ. Incidence of diagnosed polymyalgia rheumatica and temporal arteritis in the United Kingdom, 1990-2001. Ann Rheum Dis. 2006;65:1093-8.

13. Haugeberg G, Paulsen PQ, Bie RB. Temporal arteritis in Vest Agder County in southern Norway: incidence and clinical findings. J Rheumatol. 2000;27(11):2624-7.

14. Brekke LK, et al. Incidence of giant cell arteritis in Western Norway 1972-2012: a retrospective cohort study. Arthritis Res Ther. 2017;19:278.

15. Salvarani C, Macchioni P, Zizzi F, et al. Epidemiologic and immunogenetic aspects of polymyalgia rheumatica and giant cell arteritis in northern Italy. Arthritis Rheum. 1991;34:351-6.

16. Catanoso $\mathrm{M}$, Macchioni $\mathrm{P}$, Boiardi $\mathrm{L}$, et al. Incidence, prevalence, and survival of biopsy-proven giant cell arteritis in northern Italy during a 26-year period. Arthritis Care Res (Hoboken). 2017;69(3): 430-8.

17. Chandran AK, Udayakumar PD, Crowson C, et al. The incidence of giant cell arteritis in Olmsted County Minnesota, over a sixty year period 1950-2009. Scand J Rheumatol. 2015;44(3):215-8.

18. Salvarani C, Crowson CS, O'Fallon WM, Hunder GG, Gabriel SE. Reappraisal of the epidemiology of giant cell arteritis in Olmsted County, Minnesota, over a fifty-year period. Arthritis Rheum. 2004;51: 264-8. 
19. Smith CA, Fidler WJ, Pinals RS. The epidemiology of giant cell arteritis: report of a ten-year study in Shelby County, Tennessee. Arthritis Rheum. 1983;26:1214-9.

20. Salvarani $C$, et al. The incidence of giant cell arteritis in Olmsted County, Minnesota: apparent fluctuations in a cyclic pattern. Ann Intern Med. 1995;123:192-4.

21. Borchers AT, Gershwin ME. Giant cell arteritis: a review of classification, pathophysiology, geoepidemiology and treatment. Autoimmun Rev. 2012;11(6-7):A544-54.

22. Carmona FD, Gonzalez-Gay MA, Martin J. Genetic component of giant cell arteritis. Rheumatology (Oxford). 2014;53(1):6-18.

23. Carmona FD, Coit P, Saruhan-Direskeneli G, et al. Analysis of the common genetic component of large-vessel vasculitides through a meta-Immunochip strategy. Sci Rep. 2017;7:43953. https:// doi.org/10.1038/srep46012.

24. Carmona FD, Mackie SL, Martín J-E, et al. A largescale genetic analysis reveals a strong contribution of the HLA class II region to giant cell arteritis susceptibility. Am J Hum Genet. 2015;96(4):565-80.

25. Mackie SL, Taylor JC, Haroon-Rashid L, et al. Association of $H L A-D R B 1$ amino acid residues with giant cell arteritis: genetic association study, meta-analysis and geo-epidemiological investigation. Arthritis Res Ther. 2015;17(1):195.

26. Blumberg RS, van de Wal Y, Claypool S, et al. The multiple roles of major histocompatibility complex class-I-like molecules in mucosal immune function. Acta Odontol Scand. 2001;59(3):139-44.

27. Gonzalez-Gay MA, et al. Contribution of MHC class I region to genetic susceptibility for giant cell arteritis. Rheumatology (Oxford). 2007;46(3):431-4.

28. Mattey DL, Hajeer AH, Dababneh A, et al. Association of giant cell arteritis and polymyalgia rheumatica with different tumor necrosis factor microsatellite polymorphisms. Arthritis Rheum. 2000;43:174955.

29. Gonzalez-Gay MA, Hajeer AH, Dababneh A, et al. IL6 promoter polymorphism at position -174 modulates the phenotypic expression of polymyalgia rheumatica in biopsy-proven giant cell arteritis. Clin Exp Rheumatol. 2002;20:179-84.

30. Weyand CM, Goronzy JJ. Medium- and large-vessel vasculitis. N Engl J Med. 2003;349:160-9.

31. Weyand CM, Ma-Krupa W, Goronzy JJ. Immunopathways in giant cell arteritis and polymyalgia rheumatica. Autoimmun Rev. 2004;3(1):46-53.

32. Weyand CM, Goronzy JJ. Immune mechanisms in medium and large-vessel vasculitis. Nat Rev Rheumatol. 2013;9(12):731-40.

33. Deng J, Younge BR, Olshen RA, Goronzy JJ, Weyand CM. Th17 and Th1 T-cell responses in giant cell arteritis. Circulation. 2010;121:906-15.

34. Helliwell T, Muller S, Hider SL, et al. Challenges of diagnosis and management of giant cell arteritis in general practice: a multimethods study. BMJ Open. 2018;8:e019320.

35. Martinez-Taboada VM, et al. Giant cell arteritis and polymyalgia rheumatica: role of cytokines in pathogenesis and implications for treatment. Cytokine. 2008;44(2):207-20.

36. Banchereau J, Steinman RM. Dendritic cells and the control of immunity. Nature. 1998;392:245-52.

37. Ma-Krupa, et al. Trapping of misdirected dendritic cells in granulomatous lesions of giant cell arteritis. Am J Pathol. 2002;161(5):1815-23.

38. Ma-Krupa W, Jeon M-S, Spoerl S, Tedder TF, Goronzy JJ, Weyand CM. Activation of arterial wall dendritic cells and breakdown of self-tolerance in giant cell arteritis. J Exp Med. 2004;199(2):173-83.

39. Aerts-Toegaert C, Heirman C, Tuyaerts S, et al. CD83 expression on dendritic cells and $\mathrm{T}$ cells: correlation with effective immune responses. Eur J Immunol. 2007;37(3):686-95.

40. Han JW, Shimada K, Ma-Krupa W, et al. Vessel wallembedded dendritic cells induce T-cell autoreactivity and initiate vascular inflammation. Circ Res. 2008;102(5):546-53.

41. Gilden D, Nagel MA. Varicella zoster virus and giant cell arteritis. Curr Opin Infect Dis. 2016;29(3): 275-9.

42. Nagel MA, White T, Khmeleva N, et al. Analysis of varicella-zoster virus in temporal arteries biopsy positive and negative for giant cell arteritis. JAMA Neurol. 2015;72(11):1281-7.

43. Alvarez-Lafuente R, Fernandez-Guitierrez B, Jover JA, et al. Human parvovirus B19, varicella zoster virus, and human herpes virus 6 in temporal artery biopsy specimens of patients with giant cell arteritis: analysis with quantitative real time polymerase chain reaction. Ann Rheum Dis. 2005;64(5):780-2.

44. Regan MJ, Wood BJ, Hsieh YH, et al. Temporal arteritis and Chlamydia pneumoniae: failure to detect the organism by polymerase chain reaction 
in ninety cases and ninety controls. Arthritis Rheum. 2002;46:1056-60.

45. Helweg-Larsan J, Tarp B, Obel N, Baslund B. No evidence of parvovirus B19, Chlamydia pneumoniae or human herpes virus infection in temporal artery biopsies in patients with giant cell arteritis. Rheumatology. 2002;41:445-9.

46. Koster MJ, Warrington KJ. Giant cell arteritis: pathogenic mechanisms and new potential therapeutic targets. BMC Rheumatology. 2017;1:2.

47. Wagner AD, Goronzy JJ, Weyand CM. Functional profile of tissue-infiltrating and circulating CD68+ cells in giant cell arteritis. Evidence for two components of the disease. J Clin Invest. 1994;94(3): $1134-40$.

48. Unizony S, Stone JH, Stone JR. New treatment strategies in large-vessel vasculitis. Curr Opin Rheumatol. 2013;25(1):3-9.

49. Hernandez-Rodriquez J, Segarra M, Vilardell C, et al. Ischaemic events in patients with giant-cell arteritis:angiogenic activity of interleukin- 6 as a potential protective mechanism. Circulation. 2003;107(19): 2428-34.

50. Cooper AM, Dalton DK, Stewart TA, Griffin JP, Russell DG, Orme IM. Disseminated tuberculosis in interferon gamma gene-disrupted mice. J Exp Med. 1993;178:2243-7.

51. Calvalcanti YV, Brelaz MC, Neves JK, Ferraz JC, Pereira VR. Role of TNF-alpha, IFN-gamma, and IL10 in the development of pulmonary tuberculosis. Pulm Med. 2012;2012:745483.

52. Conway R, O'Neill L, McCarthy GM, et al. Interleukin 12 and interleukin 23 play key pathogenic roles in inflammatory and proliferative pathways in giant cell arteritis. Ann Rheum Dis. 2018;77(12): 1815-24.

53. Levine SM, Hellmann DB. Giant cell arteritis. Curr Opin Rheumatol. 2002;14:3-10.

54. Smetana GW, Shmerling RH. Does this patient have temporal arteritis? JAMA. 2002;287(1):92-101.

55. González-López JJ, González-Moraleja J, BurdaspalMoratilla A, Rebolleda G, Núñez-Gómez-Álvarez MT, Muñoz-Negrete FJ. Factors associated to temporal artery biopsy result in suspects of giant cell arteritis: a retrospective, multicenter, case-control study. Acta Ophthalmol. 2013;91(8):763-8.

56. Dasgupta B, Borg FA, Hassan N, et al. BSR and BHPR guidelines for the management of giant cell arteritis. Rheumatology (Oxford). 2010;49(8):1594-7.
57. Kermani TA, Schmidt J, Cynthia S, et al. Utility of erythrocyte sedimentation rate and C-reactive protein for the diagnosis of giant cell arteritis. Semin Arthritis Rheum. 2012;41:866-71.

58. Hernández-Rodríguez J, Murgia G, Villar I, et al. Description and validation of histological patterns and proposal of a dynamic model of inflammatory infiltration in giant-cell arteritis. Medicine (Baltimore). 2016;95(8):e2368.

59. Sultan H, Smith SV, Lee AG, Chévez-Barrios P. Pathologic markers determining prognosis in patients with treated or healing giant cell arteritis. Am J Ophthalmol. 2018;193:45-53.

60. Schmidt WA, Gromnica-Ihle E. Incidence of temporal arteritis in patients with polymyalgia rheumatica: a prospective study using colour Doppler ultrasonography of the temporal arteries. Rheumatology. 2002;41:46-52.

61. Ashton-Key MR, Gallagher PJ. False-negative temporal artery biopsy. Am J Surg Pathol. 1992;16:634-5.

62. Dejaco C, Ramiro S, Duftner C, et al. EULAR recommendations for the use of imaging in large vessel vasculitis in clinical practice. Ann Rheum Dis. 2018;77(5):636-43.

63. Schmidt WA, Kraft HE, Vorpahl K, Volker L, Gromnica-Ihle EJ. Color duplex ultrasonography in the diagnosis of the temporal arteritis. N Engl J Med. 1997;337:1336-42.

64. Karassa FB, Matsagas MI, Schmidt WA, Ioannidis JP. Meta-analysis: test performance of ultrasonography for giant-cell arteritis. Ann Intern Med. 2005;142:359-69.

65. Arida A, Kyprianou M, Kanakis M, Sfikakis PP. The diagnostic value of ultrasonography-derived edema of the temporal artery wall in giant cell arteritis: a second meta-analysis. BMC Musculoskelet Disord. 2010;11:44.

66. Ball EL, Walsh SR, Tang TY, Gohil R, Clarke JM. Role of ultrasonography in the diagnosis of temporal arteritis. Br J Surg. 2010;97:1765-71.

67. Aschwanden M, Imfeld S, Staub D, et al. The ultrasound compression sign to diagnose temporal giant cell arteritis shows an excellent interobserver agreement. Clin Ex Rheum. 2015;33(sup 89):s113-5.

68. Luqmani R, Lee E, Singh S, et al. The role of ultrasound compared to biopsy of temporal arteries in the diagnosis and treatment of giant cell arteritis (TABUL): a diagnostic accuracy and cost-effectiveness study. Health Technol Assess. 2016;20(90). 
69. Croft A, Thompson N, Duddy M, et al. Cranial ultrasound for the diagnosis of giant cell arteritis. A retrospective cohort study. J R Coll Physicians Edinb. 2015;45(4):268-72.

70. Blockmans D, de Ceuninck L, Vanderschueren S, Knockaert D, Mortelmans L, Bobbaers H. Repetitive 18F-fluorodeoxyglucose positron emission tomography in giant cell arteritis: a prospective study of 35 patients. Arthritis Rheum. 2006;55(1):131-7.

71. Klink T, Geiger J, Both M, et al. Giant cell arteritis: diagnostic accuracy of MR imaging of superficial cranial arteries in initial diagnosis-results from a multicenter trial. Radiology. 2014;273(3):844-52.

72. Mollan S, Keane P, Denniston A. The use of transdermal optical coherence tomography to image the superficial temporal arteries. Eye. 2017;31(1): 157-60.

73. Mollan SP, Begaj I, Mackie S, et al. Increase in admissions related to giant cell arteritis and polymyalgia rheumatica in the UK, 2002-13, without a decrease in associated sight loss: potential implications for service provision. Rheumatology (Oxford). 2015;54(2):375-7.

74. Buttgereit F, Matteson EL, Dejaco C, Dasgupta B. Prevention of glucocorticoid morbidity in giant cell arteritis. Rheumatology (Oxford). 2018;57(2):ii11-ii21.

75. Proven A, Gabriel SE, Orces C, O'Fallon WM, Hunder GG. Glucocorticoid therapy in giant cell arteritis: duration and adverse outcomes. Arthritis Rheum. 2003;49:703-8.

76. Spiera RF, Mitnick HJ, Kupersmith $M$, et al. A prospective, double-blind, randomized, placebocontrolled trial of methotrexate in the treatment of giant cell arteritis (GCA). Clin Exp Rheumatol. 2001;19:495-501.

77. Jover JA, Hernandez-Garcia C, Morado IC, Vargas E, Banares A, Fernandez-Gutierrez B. Combined treatment of giant-cell arteritis with methotrexate and prednisone. A randomized, double-blind, placebocontrolled trial. Ann Intern Med. 2001;134:106-14.

78. Hoffman GS, Cid MC, Hellmann DB, et al. A multicenter, randomized, double-blind, placebo-controlled trial of adjuvant methotrexate treatment for giant cell arteritis. Arthritis Rheum. 2002;46:1309-18.

79. Mahr AD, et al. Adjunctive methotrexate for treatment of giant cell arteritis: an individual patient data meta-analysis. Arthritis Rheum. 2007;56:2789-97.

80. Adizie T, Christidis D, Dharmapaliah C, Borg F, Dasgupta B. Efficacy and tolerability of leflunomide in difficult-to-treat polymyalgia rheumatica and giant cell arteritis: a case series. Int J Clin Pract. 2012;66:906-9.

81. Diamantopoulos AP, Hetland H, Myklebust G. Leflunomide as a corticosteroid-sparing agent in giant cell arteritis and polymyalgia rheumatica: a case series. Biomed Res Int. 2013;2013:120638.

82. Hočevar A, Ješe R, Rotar Ž, et al. Clin Rheumatol. 2018. https://doi.org/10.1007/s10067-018-4232-x.

83. De Silva M, Hazleman BL. Azathioprine in giant cell arteritis/polymyalgia rheumatica: a double-blind study. Ann Rheum Dis. 1986:45(2):136-8.

84. Quartuccio L, Maset M, De Maglio G, et al. Role of oral cyclophosphamide in the treatment of giant cell arteritis. Rheumatology. 2012;51:1677-86.

85. Sciascia S, Piras D, Baldovino, et al. Mycophenolate mofetil as steroid-sparing treatment for elderly patients with giant cell arteritis: report of three cases. Aging Clin Exp Res. 2012;24(3):273-7.

86. Schaufelberger C, Mollby H, Uddhammar A, et al. No additional steroid-sparing effect of cyclosporine A in giant cell arteritis. Scand J Rheumatol. 2006;55(4):327-9.

87. Mollan SP, Sharrack N, Burdon MA, Denniston AK. Aspirin as adjunctive treatment for giant cell arteritis. Cochrane Database Syst Rev. 2014;(8):CD010453.

88. Villiger PM, Adler S, Kuchen S, et al. Tocilizumab for induction and maintenance of remission in giant cell arteritis: a phase 2, randomised, double-blind, placebo-controlled trial. Lancet. 2016;387:1921-7.

89. Stone JH, Tuckwell K, Dimonaco S, et al. Trial of tocilizumab in giant cell arteritis. N Engl J Med. 2017;377(4):317-28.

90. Mollan SP, Horsburgh J, Dasgupta B. Profile of tocilizumab and its potential in the treatment of giant cell arteritis. Eye Brain. 2018;23(10):1-11.

91. United States Food and Drug Administration (FDA). FDA approves first drug to specifically treat giant cell arteritis. May 2017. https://www.fda.gov/news events/newsroom/pressannouncements/ucm559791. htm.

92. Hoffman GS, et al. Infliximab for maintenance of glucocorticosteroid-induced remission of giant cell arteritis: a randomized trial. Ann Intern Med. 2007;146:621-30.

93. Seror R, et al. Adalimumab for steroid sparing in patients with giant-cell arteritis: results of a 
multicentre randomised controlled trial. Ann Rheum Dis. 2013;73:2074-81.

94. Martínez-Taboada VM, et al. A double-blind placebo controlled trial of etanercept in patients with giant cell arteritis and corticosteroid side effects. Ann Rheum Dis. 2008;67:625-30.

95. Conway R, O’Neill L, O’Flynn E, et al. Ustekinumab for the treatment of refractory giant cell arteritis. Ann Rheum Dis. 2016;75:1578-9.

96. ClinicalTrials.gov. Unizony, S: National Library of Medicine (US). 2016 Nov 4. Identifier NCT02955147, Ustekinumab for the treatment of giant cell arteritis (UGCA). https://clinicaltrials.gov/ ct2/show/NCT02955147?cond=giant+cell+arteritis\& rank=22.

97. Langford CA, Cuthbertson D, Ytterberg SR, et al. A randomised double-blind trial of abatacept (CTLA4Ig) for the treatment of giant cell arteritis. Arthritis Rheumatol. 2017;69(4):837-45.
98. Ly KH, Stirnemann J, Liozon E, et al. Interleukin-1 blockade in refractory giant cell arteritis. Joint Bone Spine. 2014;81(1):76-8.

99. ClinicalTrials.gov. National Library of Medicine (US). 2016 Sept 16. Identifier NCT02902731, Giant cell arteritis and Anakinra Trial (GiAnT). https:// clinicaltrials.gov/ct2/show/NCT02902731?term=anak inra\&cond=giant + cell+arteritis\&rank=1.

100. Dasgupta B. A randomized, double-blind, placebocontrolled study to assess the efficacy and safety of gevokizumab in the treatment of giant cell arteritis. Rheumatology. 2014;53(2); i7.

101. Bhatia A, Ell PJ, Edwards JC. Anti-CD20 monoclonal antibody (rituximab) as an adjunct in the treatment of giant cell arteritis. Ann Rheum Dis. 2005;64: 1099-100.

102. ClinicalTrials.gov. Koster MJ: National Library of Medicine (US). 2017 Jan 20. Identi fier NCT03026504, Baricitinib in relapsing giant cell arteritis. https://clinicaltrials.gov/ct2/show/NCT0 3026504?term $=$ Baricitinib\&cond $=$ giant + cell + arterit is\&rank $=1$. 